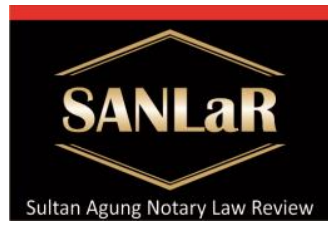

Volume 3 No. 1, March 2021
Sultan Aqung

Notary Law Review

Systematic \& Complete Land Registration...(A. Hasdian Ikawati)
ISSN 2686-4428

published by

Master of Notarial Law Faculty of Law Semarang

\title{
Systematic \& Complete Land Registration Effectiveness in Reducing Land Disputes in Kendari City
}

\author{
A. Hasdian Ikawati ${ }^{*}$ ) \\ *) Student of Master of Notary Law, Faculty of Law, Universitas Islam Sultan \\ Agung (UNISSULA) Semarang
}

\begin{abstract}
The importance of systemic and complete land registration in its development has not been able to materialize effectively, this has resulted in widespread problems of land ownership disputes in the community. The writing of this article uses an empirical juridical method. Based on existing research, it can be seen that the implementation of a complete and systemic registration is important in preventing land disputes. However, this has not been effective due to the problem of overlapping regulations and the problem of people's perspectives who still do not understand the importance of land registration at this time. So that the efforts made to overcome the obstacles that arise in the implementation of land registration are by providing legal counseling to the community, so that residents get sufficient legal information and knowledge to support the implementation of proper land registration. For the payment of BPHTB (Land Rights Acquisition Fee) for residents who cannot afford to have received relief in the payment.
\end{abstract}

Keywords: Effectiveness; Registration; Disputes; Land.

\section{Introduction}

Government Regulation No. 24/1997 is one of the operational steps to carry out systematic land registration, namely by registering all land parcels in a village area or part of it. Land registration in this way is considered to provide greater results in a relatively short period of time, because the collection of land registration data is carried out simultaneously on all land parcels in a village and the wider community is aware that land registration is taking place, so that the objections raised there is immediately known anyway.

In addition, the systematic land registration method also produces a land registration map containing maps of registered land parcels in a consolidated manner and connected to certain binding points, so that later boundary reconstruction can be carried out easily. Thus it can be avoided the existence of disputes regarding the boundaries of land parcels which are still frequent 
Problems that have existed in the community are obliged to be resolved in search of solutions. Based on these matters, in order to improve and improve services to the community in the land sector, the National Land Agency of the Republic of Indonesia has made new breakthroughs to solve problems that exist in society to carry out land registration of all land parcels in Indonesia.

The real form of the seriousness of the National Land Agency of the Republic of Indonesia in dealing with problems that arise in society through agrarian reform policies, especially for people with weak economies, is to create strategic programs. These strategic programs are expected to be a tool to reduce and solve problems that exist in society. These programs, for example, include the Prona Land Certification program (National Agrarian Operation Project), UKM Land Certification (Land Certification for Small Businesses and Micro Enterprises), MBR Land Certification (Low Income Community Land Certification), Agricultural Land Certification, Fisherman Land Certification, and Transmigration Land Certification.

Some of the types of dispute typologies mentioned above are disputes over boundaries / locations of land parcels, namely disputes arising between two parties who have rights to land or land that are adjacent to each other, due to misunderstanding of the extent and boundaries of their land. Examples of land parcel boundary / location disputes are overlap, confiscation of land parcels and control of land parcels that are not in accordance with proof of ownership of rights. In this case the Measure Drawing function must be able to be used for reconstruction or the return measurement of land parcels by whoever the Land Office measuring officer and not only fixated on the measuring officer who carried out the measurement of the land parcel for the first time.

Reconstruction or measurement of the return of the boundary of the land parcel is carried out on certificates whose boundary marks have been lost and / or certificates whose location and position are no longer known, as well as in the context of resolving land disputes that have not yet reached the legal framework or those that have entered legal channels (police and court investigations. ) as; overlapping certificates, double certificates, certificates where the land parcel is not suitable for the physical control in the field by the right holder (two or more certificates whose physical control is exchanged with one another), boundary disputes, measurement of boundary returns in the context of investigating and investigating land crimes as well as field trial (local examination) by a panel of judges and so on. 
Based on the above description and to find out to what extent the implementation of systematic land registration affects land disputes, it is necessary to conduct a deeper discussion regarding "The Effectiveness of Systematic and Complete Land Registration in Reducing Land Disputes in Kendari City."

\section{Research Methods}

The research used in this paper is the empirical juridical method, namely legal research that relies on primary data (results from field research). The juridical approach is an approach that focuses on existing rules and regulations, while the empirical approach is the approach carried out by field research by observing and observing the application of these regulations in practice in society. The purpose of writing in this article is to analyze and describe problems related to the effectiveness of systematic and complete land registration in reducing land disputes in Kendari City.

3. Result and Discussion

\subsection{Current Systemic Land Registration Implementation}

Based on Article 1 paragraph (2) Regulation of the Minister of Agrarian and Spatial Planning / Head of the National Land Agency of the Republic of Indonesia Number 12 of 2017 concerning the Acceleration of Complete Systematic Land Registration, it is explained that Complete Systematic Land Registration, hereinafter abbreviated as PTSL, is the first Land Registration activity which is carried out simultaneously Simultaneously for all Land Registration objects throughout the territory of the Republic of Indonesia in one village or other similar name, which includes the collection and determination of the correctness of physical data and juridical data regarding one or several Land Registration objects for the purpose of registration. ${ }^{1}$

The implementation of systematic land registration in its implementation is often associated with the term Adjudication. The word Adjudication is a technical term in land registration which has the meaning: activities and

\footnotetext{
${ }^{1}$ Auliyaa Martati dan Lego Karjoko. (2017). Implementasi Asas Akuntabilitas Dalam Pendaftaran Tanah Secara Sistematik Berdasarkan Peraturan Menteri Agraria Dan Tata Ruang/Kepala Badan Pertanahan Nasional Republik Indonesia Nomor 12 Tahun 2017 Tentang Percepatan Pendaftaran Tanah Sistematis Lengkap, Semarang, Tesis, Master of Notary Law, Faculty of Law, Universitas Sebelas Maret Surakarta. p. 36.
} 
processes in the framework of systematic land registration for the first time, in the form of collecting and verifying the correctness of physical and juridical data regarding a plot of land or more for the purposes of registration. Furthermore, Boedi Harsono stated that what is meant by adjudication is an activity carried out in the framework of the land registration process for the first time, including the collection and determination of the correctness of physical data and juridical data regarding one or several objects of land registration for the purpose of registration. ${ }^{2}$

The following are the stages of implementing Complete Systematic Land Registration (PTSL) which are divided into several stages, namely, as stipulated in the Regulation of the Minister of Agrarian and Spatial Planning / Head of the National Land Agency of the Republic of Indonesia Number 6 of 2018 concerning complete systemic registration:
a. Plan;
b. Location determination;
c. Preparation;
d. Establish and determine the PTSL adjudication committee and task force;
e. Counseling;
f. Physical data collection and juridical data collection;
g. Juridical data research to prove rights;
h. Announcement of physical data and juridical data and validation thereof;
i. Confirmation of conversion, recognition of rights and granting of rights;
j. Bookkeeping rights;
k. Issuance of a certificate of land rights;
I. Documentation and submission of the results of activities; and
m. Report.

\subsection{Barriers to Systemic Land Registration Implementation}

Based on the research that has been done by the author, it can be seen that some of the obstacles that arise in implementing Land Registration in Kendari City, namely:

a. Lack of knowledge of residents about land law, so that many letters of transfer of adjudication and prona ownership that are owned by residents are only receipts or are found to be incomplete in the order of ownership.

Ilbid, p. 25. 
b. The large number of adjudication and prona participants whose economic conditions are low, so that the obligation to pay Land and Building Tax for years has not been paid so that determining BPHTP payments is a separate obstacle.

c. A lot of time is consumed to provide direction on disputes between the parties, because the problem of proof of ownership or boundaries in the field does not match the proof of ownership on the other side.

d. The low interest in participation from the community, this can be seen when officers from the land office came to the location that had been designated as the PTSL location, but when the officers knocked on the residents' doors to conduct socialization, and were told that their land would be measured, the people were busy. If the desire to participate in PTSL activities does not yet exist, then the assigned committee must be able to convince the community that the presence of PTSL can have a positive impact, and benefit the community itself. For example, it can be socialized that PTSL not only produces an output in the form of a certificate, but the most important thing is to register every land parcel in Indonesia as well as to fix existing certificates, and to suppress land disputes. The holder of the right can be given a certificate, not just a facility, but over land, which is guaranteed by law.

The ineffectiveness of complete systematic land registration in the legal system theory study is influenced by the substance of the law, which in this case is influenced by legal regulations in the land sector. The legal substance in the land sector regulated in the UUPA and the prevailing laws and regulations has not been able to promote legal awareness of the community. This is because the substance of the UUPA has not succeeded in becoming a social engineering tool in raising legal awareness of the community to carry out land registration. As a result, government programs to accelerate land registration have not run optimally.

Law as a tool for social engineering, in addition to being regulatory in nature, must also be coercive. The coercive nature of the law embodied in a legal product (statutory regulation) will be effective if there are sanctions against the implementation or violation of the provisions stipulated by law. The substance of Article 23 paragraph (1) of the UUPA, confirms that ownership rights, as well as any transfer of building use rights and other assignments of rights must be registered according to the provisions referred to in Article 19. This provision explicitly requires holders of property rights to register every transfer of rights. ownership of land, whether it is a transfer of 
property rights due to buying and selling, grants and so on. However, the provisions of Article 23 paragraph (1) of the UUPA which are imperative have no force,

There are no sanctions for holders of land rights who do not and have not registered their land rights in the UUPA and Government Regulation Number 24 of 1997 concerning Land Registration, causing the provisions of Article 23 paragraph (1) to be ineffective. Talking about the effectiveness of the law in society means talking about the working power of the law in regulating and or forcing people to obey the law the effectiveness of the law means studying the rules that must meet the requirements, namely to apply juridical, sociologically, and philosophically. ${ }^{3}$

Efforts made to overcome the obstacles that arise in the implementation of land registration are by providing legal counseling to the community, so that residents can obtain sufficient legal information and knowledge to support the implementation of proper land registration. For the payment of BPHTB (Land Rights Acquisition Fee) for residents who cannot afford it, they have received relief in the payment.

\subsection{Factors Causing Land Disputes}

One area that regulates the life order of citizens who are also subject to the law, namely the land sector. Article 33 paragraph (3) of the 1945 Constitution and spelled out in the UUPA which regulates agrarian / land issues in Indonesia as a regulation that must be obeyed. One of the objectives of the formation of the UUPA is to lay the foundations for providing legal certainty regarding land rights for the people as a whole. If seen factually the juridical basis that regulates agrarian / land issues is not fully implemented consequently for various reasons that cause problems. The current sources of land problems / conflicts include:

a. Ownership / land tenure that is not balanced and uneven

b. Incompatible use of agricultural land and non-agricultural land.

c. Lack of siding with people with weak economic groups.

d. Lack of recognition of customary law community rights to land such as ulayat rights.

e. Weak bargaining position of communities holding land rights in land acquisition.

He continued, general causes of land conflicts can be grouped into two factors, namely: legal factors and non-legal factors.

${ }^{3}$ Faried Ali. (1997). Hukum Tata Pemerintahan dan Proses Legislatif Indonesia. Jakarta:

Rajagrafindo Persada. p. 94. 
a. Law office

This Law Office consists of two parts, namely: overlapping laws and regulations and overlapping judiciary.

1) What is meant by overlapping regulations, for example the UUPA as the parent of regulations in the field of agrarian resources, but in the making of other regulations it does not place the UUPA as the main law so that it contradicts new sectoral laws such as the Forestry Law and Basic Laws. Mining and Investment Law;

2) And what is meant by overlapping judiciary, for example, currently there are three judicial institutions that can handle a land conflict, namely civil, criminal and state administration. In certain forms of conflict, one of the parties who wins in civil terms does not necessarily win criminally (in the case of a conflict accompanied by a criminal act) or will win in a state administration (in the state administration court).

b. Non-Legal Officers

Non-legal factors that are at the root of land conflicts include overlapping land uses, high land economic value, increased community awareness of land use, reduced land while the community continues to grow, and because of poverty factors. :

1) Overlapping land use, that is, over time the rapid population growth causes the population to increase, while food production remains or may decrease because a lot of agricultural land has changed its function.

2) The economic value of land is high, that is, the day the land has increased its selling price in the market, land has become one of the promising objects for the community, both for opening plantation business areas, rice fields, settlements and land for industrial estates.

3) Increased public awareness, namely the existence of global developments and an increase in the development of science and technology have an effect on increasing public awareness. With regard to land as a development asset, a change in the mindset of the community towards land ownership is that there is no longer placing land as a means for investment or economic commodity.

4) Land remains permanent while the population increases, namely rapid population growth through both birth and 
migration and urbanization, as well as the constant amount of land, making land an economic commodity of very high value, so that every inch of land is maintained as strong as possible.

5) Poverty, which is a complex problem that is influenced by various interrelated factors. Limited access to land cannot be avoided that in the same plot of land different interests can arise is one of the factors causing poverty in terms of

4. Closing limited assets and accessible productive resources.

Complete and systemic registration is essential in preventing land disputes. However, this has not been effective due to the problem of overlapping regulations and the problem of people's perspectives who still do not understand the importance of land registration at this time.

\section{References}

Books:

[1] Auliyaa Martati dan Lego Karjoko. (2017). Implementasi Asas Akuntabilitas Dalam Pendaftaran Tanah Secara Sistematik Berdasarkan Peraturan Menteri Agraria Dan Tata Ruang/Kepala Badan Pertanahan Nasional Republik Indonesia Nomor 12 Tahun 2017 Tentang Percepatan Pendaftaran Tanah Sistematis Lengkap, Semarang, Tesis, Master of Notary Law, Faculty of Law, Universitas Sebelas Maret Surakarta.

[2] Faried Ali. (1997). Hukum Tata Pemerintahan dan Proses Legislatif Indonesia. Jakarta: Rajagrafindo Persada

[3] Fuady Munir. (2014). Teori-Teori Besar Dalam Hukum (Grand Theory). Cetakan ke-3. Jakarta: Prenadamedia Group. Internet:

[1] https://www.kompas.com/skola/read/2020/03/23/080000469/k needshuman - primary-secondary tertiary? page $=$ all, Retrieved October 20, 2020

[2] http://landportal.blogspot.com/2014/07/pengentuk-gambar-ukur.html, Retrieved October 20, 2020

[3] http://www.bpn.go.id/Program-Prioritas/Pegangan-Kasus-Pertanahan. Retrieved November 14, 2020

[4] https://www.kendarikota.go.id/berita/bapenda-kota-kendari-gelarrakor-bahas- land-registration-program / accessed on February 11, 2021, at 14.58 WITA 